\title{
SNOW ACTION ON MOUNT TWYNAM, SNOWY MOUNTAINS, AUSTRALIA
}

\author{
By A. B. Costin \\ (Commonwealth Scientific \& Industrial Research Organisation, Canberra, A.C.T., Australia) \\ J. N. Jennings \\ (Australian National University, Canberra, A.C.T., Australia) \\ H. P. BLACK \\ (Department of Meterorology, University of Melbourne, Melbourne, Victoria, Australia) \\ and B. G. Тном \\ (Louisiana State University, Baton Rouge, Louisiana, U.S.A.)
}

\begin{abstract}
A commonly accepted distinction between snow-patches and glaciers is the slow mass movement of the latter with consequent abrasion of stones and rock surfaces. However, the observations of some workers do not support this distinction. The present study, in a snow-patch area on Mount Twynam in the Snowy Mountains (Australia), presents positive evidence of slow mass sliding of snow, causing transport, abrasion and detachment of stones and abrasion of the bedrock surface. Consequently, no sharp separation is possible between the erosional effects of snow-patches and small cirque glaciers. In areas such as the Snowy Mountains the relative importance of glacial and nivational processes becomes more difficult to
evaluate.
\end{abstract}

RÉsumé. Une distinction d'usage courant entre les plaques de neige et les glaciers tient dans le mouvement d'ensemble lent de ces derniers et dans l'abrasion des pierres et des surfaces rocheuses qui en résulte. Cependant, les observations de quelques travailleurs n'admettent pas cette différentiation.

L'étude actuelle d'une plaque de neige sur le Mont Twynam dans les Snowy Mountains (Australie) offre l'évidence absolue d'un glissement lent de la neige dans la masse, qui est responsable du transport, de l'abrasion et de l'arrachement des pierres, ainsi que de l'abrasion des surfaces rocheuses. Par conséquent, on ne peut différencier nettement les effets de l'érosion due aux plaques de neige de ceux de l'érosion produite par les petits glaciers de cirque. Dans les régions telles que les Snowy Mountains, l'importance relative des processus glaciaires et nivaux devient plus difficile à évaluer.

Zusammenfassung. Nach allgemeiner Annahme gilt, dass sich Gletscher von Firnflecken durch ihre langsame Massenbewegung unterscheiden, welche die Abrasion von Steinen und Felsoberflächen zur Folge hat. Diese Unterscheidung wurde jedoch durch die Beobachtungen einiger Forscher in Frage gestellt.

Die vorliegende Untersuchung, die an Firnflecken im Gebiet des Mount Twynam in den Snowy Mountains (Australien) durchgeführt wurde, ergab klare Anzeichen von langsamem Gleiten der Schneemassen, das Verlagerung, Abrasion und Loslösung von Steinen sowie Abrasion des Felsuntergrundes bewirkte. Eine scharfe Trennung der Erosionswirkungen von Firnflecken und kleinen Kargletschern ist daher unmöglich. Die relative Bedeutung glazialer und nivaler Vorgänge lässt sich in Gebieten wie den Snowy Mountains nur
schwer ermitteln.

\section{Historical Introduction}

The processes of nivation and the resulting landforms have received less attention than other aspects of the geomorphology of cold climates. Divergence of view is therefore to be expected. Matthes (I900) to whom we owe the term "nivation", found no evidence of scour or transport of material in snow-patch hollows and so inferred an absence of slow mass movement in snow as opposed to avalanche movement. On the other hand, Bowman (19i6) constructed a graph of snow motion in terms of slope and thickness on the basis of inference from nivational land-forms. At the same time he denied snow the power of abrasion and striation although crediting it with that of plucking.

However, it was not long afterwards that A. N. Lewis (1925) recorded fresh striations in weak coal measures near the summit of La Perouse in Tasmania, which he confidently ascribed to a seasonal snow-patch. In an account of nivation in the Vosges, Rempp and 
Rothé (1934) referred to "un lent travail d'érosion, qui se manifeste par des arrachements du sol bien visible en été à l'emplacement de ces névés". Dyson (1937, I938) discussed more fully fresh striations on the weathering rind of limestones near Blackfleet and Sperry Glaciers, Glacier National Park, Montana. Though associated with undoubted glacial striae and grooves, these fresh ones were regarded on good grounds as not of similar origin but due to snow action. In fact Dyson inferred rapid, avalanche motion, without really considering the possibility of slow snow movement. Dyson regarded his work as corroborative of slightly earlier findings from the Japanese Alps by Imamura and Hirabayasi (1935; Imamura 1937, I938), in which, in these regions of heavy snowfall, striations and roches moutonnées are regarded as the result of present-day nivational processes. However, these latter authors do not commit themselves as to the nature of the snow movement involved.

Almost contemporaneously, careful examination of snow-patches in eastern Iceland failed to lead W. V. Lewis (1936, r 939) to any conception of mass movement of the snow with accompanying abrasion, striation or plucking. Comparable work in Spitsbergen by McCabe (1939) had the same result. From Russian examples, Boch (1946, 1948)* agreed in the main with W. V. Lewis, though he stressed the significance of the weight of snow, both in compacting stones into pavement and in promoting solifluction beneath the patches. Moreover he seems to allow of mass movement of snow, together with subjacent rock debris, on steep rock walls at more than 30 degrees. In so far as Lewis and Boch differed, Boyé (1952) supported the former's views and returned to Matthes' standpoint that the essential distinction between snow-patches and glaciers resided in the slow mass movement of the latter. Yet at much the same time, Haefeli (1953) had no doubt at all about slow sliding ("creep") of snow covers on the basis both of field observations and laboratory experiments. This he maintained was of geomorphological importance, "... we observe in mountains with a thick snow cover that solifluction and skin creep is activated not only by climatic effects such as frost, temperature, weathering, etc., but in the first place by the creep pressure within the snow cover". More recently, Maruszczak (I96I) has referred briefly to the transport of blocks in the interior of permanent snow-patches in the Pirin and Vitocha areas of Bulgaria. Unpublished work by Andrews (referred to in Williams, 1962) indicated that the deformation of trees in Labrador was due to creep of large masses of snow in winter. In a context of such diversity of experience and opinion there is clearly room for further investigation. $\uparrow$

\section{Eastern Cirque of Mount Twynam, Snowy Mountains}

Though the extent and nature of Pleistocene glaciation in the Snowy Mountains (Fig. I) are still in debate (Browne and Vallance, 1957; Galloway, 1963), there is no question but that there was a phase of cirque glaciation. The eastern cirque of Mount Twynam is not the most elaborate product of this cirque glaciation but it has the distinction of maintaining snow longer than any other site in the Snowy Mountains. A long-lasting snow-patch is found on the upper part of the high north-west wall of this cirque below the summit of Mount Twynam $(2,197$ m.) (Fig. 2); its final remnants are found in a deep gully in this wall, facing south-east

* These Russian papers were read in translation only.

+ Whilst this paper was in the press, two further items of relevant literature reached Canberra. In Fryxell (1962) is reprinted a paper by Mathes later than the one cited above; it is Matthes (191 I), of which the gist had previously appeared in Matthes ( 1909 ). Matthes discusses white stripes on bedrock surfaces similar to those described here. Though few stones were found in association with the marks, the latter are attributed to the slow creep of stones, thought to be due to various agencies but especially to winter snow. He describes the stripes as due solely to the absence of lichens and mosses, which cover the surrounding surfaces. This absence is not ascribed to abrasion but is regarded as a consequence of a pad of loose rock grains beneath the moving stones. Lichens are said not to live beneath a film of sand. Matthes had evidently changed his views from the time of the earlier paper cited by us and had moved closer to the standpoint supported by the present contribution.

The second item is Mathews and Mackay ( 1963$)$, in which instrumentation for and records of measurements of snow creep are dealt with. Our observations and inferences are in good accord with their results. 


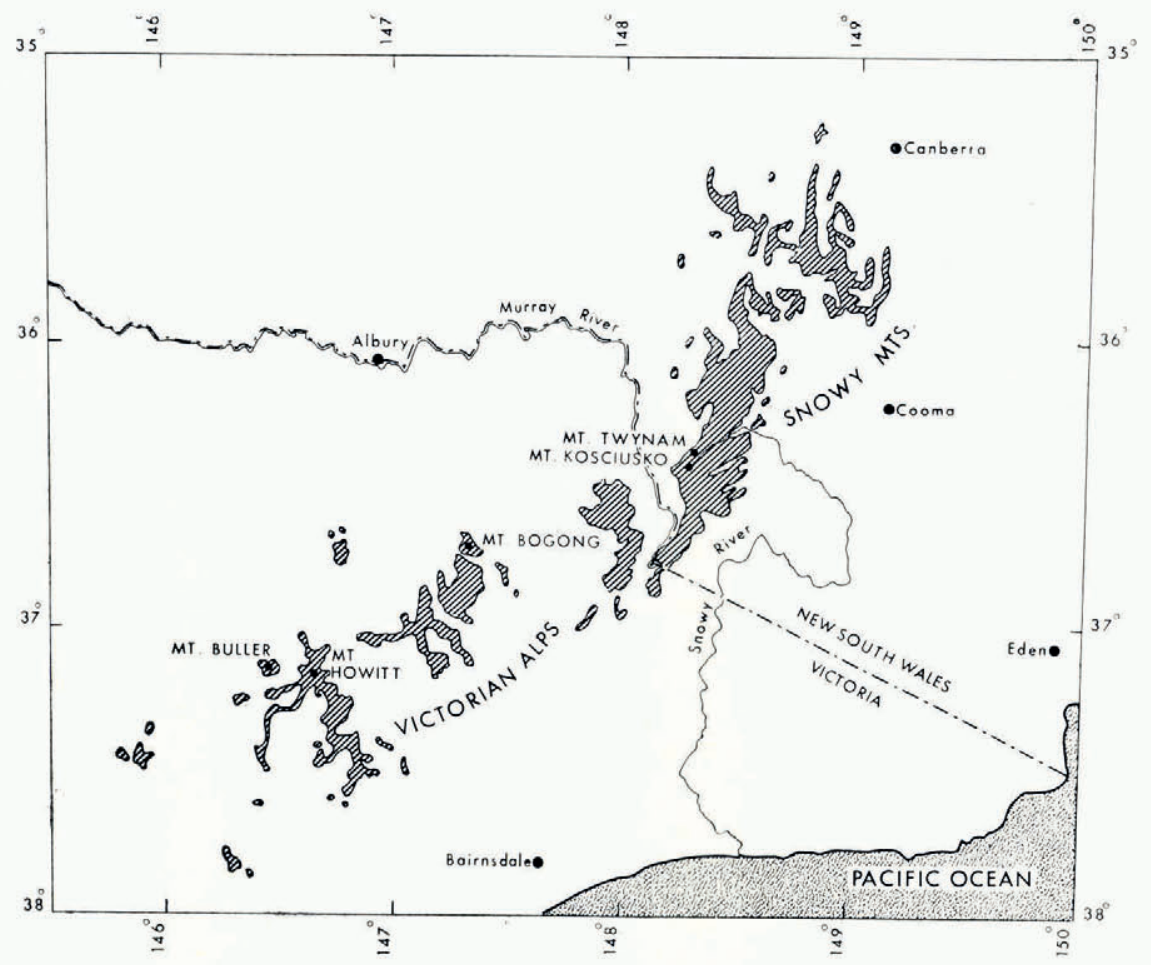

Fig. I. Map of south-eastern Australia showing localities mentioned. Hatched areas comprise land above 4,500 ft. ( $1,372 \mathrm{~m}$.

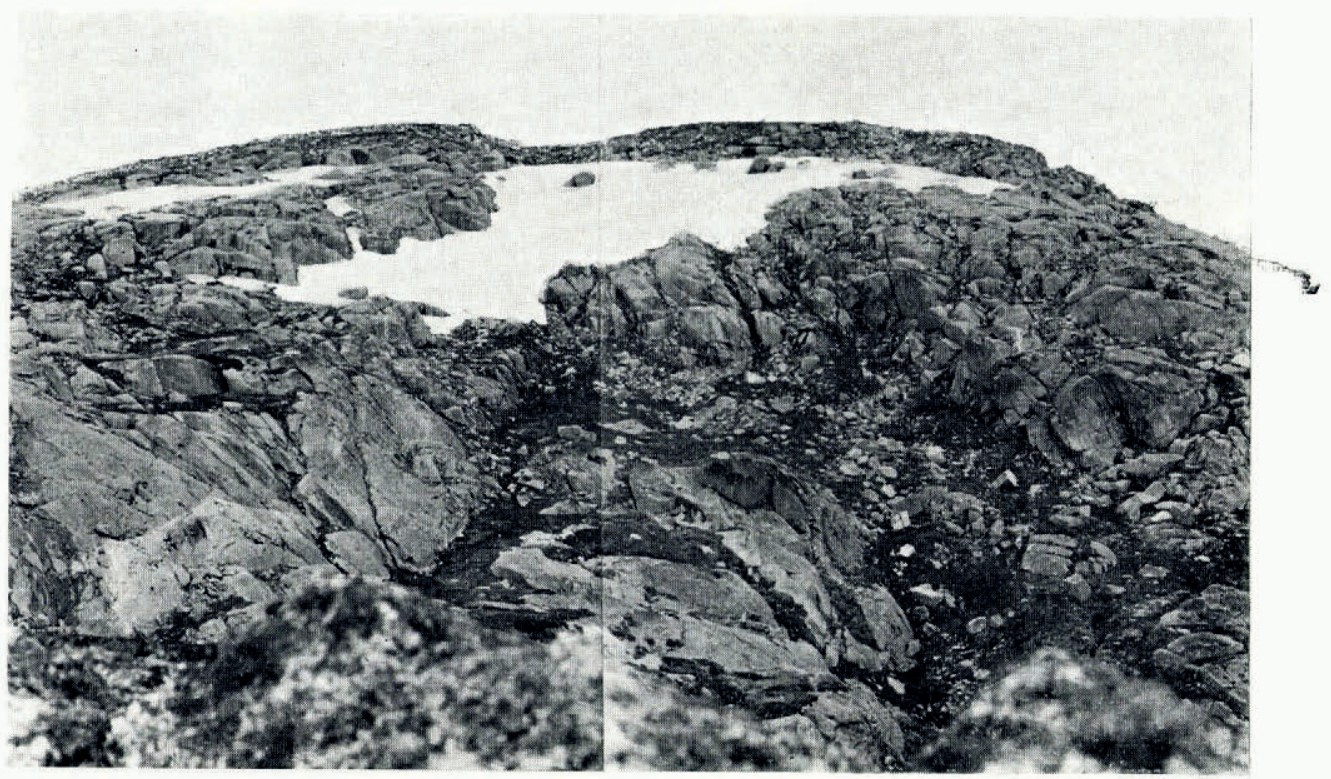

Fig. 2. Early spring condition of the north-west wall of Mount Twynam eastern cirque showing snow-patch. (Photograph by H. P. Black) 
at an elevation of 2,100 m. and it has been observed to carry over from one year to another. The greater persistence of this snow-patch compared with others on the southern sides of Mount Townsend and Mount Kosciusko, which are in some respects more favourably placed, is probably a result of its greater thickness, which is estimated to attain some $40 \mathrm{~m}$. This thickness is due primarily to the very sheltered and high-lying position of this cirque in the lee of the extensive, gently sloping summit area of Mount Twynam to the west, the direction from which most snow comes in this area.

\section{Snow Transport of Stones and Abrasion}

Towards the end of summer in March 1962, initial observations of fresh, white abrasion marks down slabby bedrock surfaces of granodiorite and of accompanying freshly abraded loose stones were made near the final snow remnant. The obvious inference was one of transport by the snow but at this stage the data were insufficient for certainty about this interpretation. Therefore several small stones in the vicinity of these observations were painted, together with the bedrock locations, to obtain direct information about the process. Before winter, the snow-patch disappeared completely.

On I6-i 7 February I 963 at least Ioo instances of fresh abrasion marks and accompanying stones were seen above and to the flanks of the considerable area of snow remaining at that date. Measurements were taken of 34 stones and their tracks. The smallest measured $6 \times 6 \times 2.5 \mathrm{~cm}$. with a track of $53 \mathrm{~cm}$., the largest $86 \times 77 \times 30 \mathrm{~cm}$. with a track of $280 \mathrm{~cm}$.* The median, using $L \times l \times H$ as the measure of size, lay between two stones, measuring $17.5 \times 10 \times 7.5 \mathrm{~cm}$. (track $400 \mathrm{~cm}$.) and $18 \times 14 \times 6 \mathrm{~cm}$. (track $155 \mathrm{~cm}$.). The minimum track length measured was $15 \mathrm{~cm}$., the longest $630 \mathrm{~cm}$. and the median I $55 \mathrm{~cm}$.

The directions of movement were all down the general slope $\left(25^{-30}\right.$ degrees $)$ of the cirque wall, which meant there was a slightly centripetal arrangement. Most of the tracks consequently ran down the maximum slope of the specific rock slab they marked (Fig. 3). The vertical angle of these down-slope tracks varied between 2 and 30 degrees, though instances were found of tracks going over the strongly abraded lips of vertical drops at the bottom of

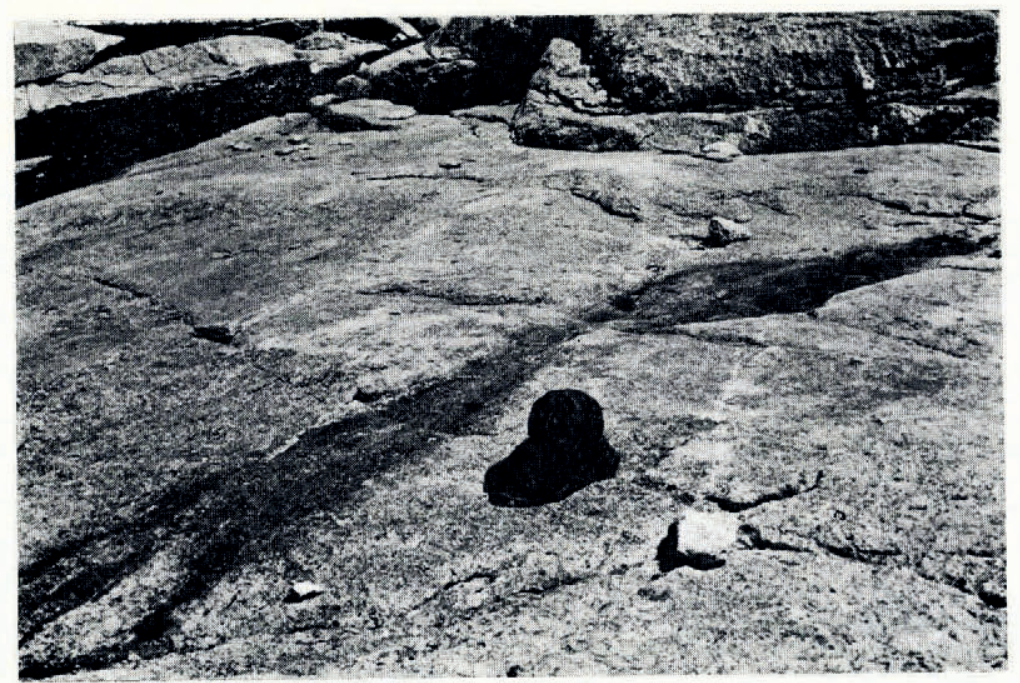

Fig. 3. Down-slope movement of two stones to left and right of hat. These are painted stones, which moved from the top of the low angle slope in $1962-63$ season. (Photograph by C.S.I.R.O.)

* The dimensions are $L=$ greatest length in the principal plane, $l=$ greatest width at right angles to $L$ in the principal plane, and $H=$ greatest thickness perpendicular to the principal plane. 
which freshly abraded stones lay. But the detailed rock sculpture necessarily involved local slopes at variance with the general fall of the cirque side. As a result, of the 34 stones measured, 5 had down-slope tracks but making an angle with the maximum slope of the rock slab concerned (Fig. 4), 6 had tracks at right angles to the slope and 4 had moved uphill over part or the whole of their tracks (Fig. 5). Two stones were left in precarious balance on the lip of vertical drops.

Fresh abrasion surfaces on different faces of three stones showed they had been turned over

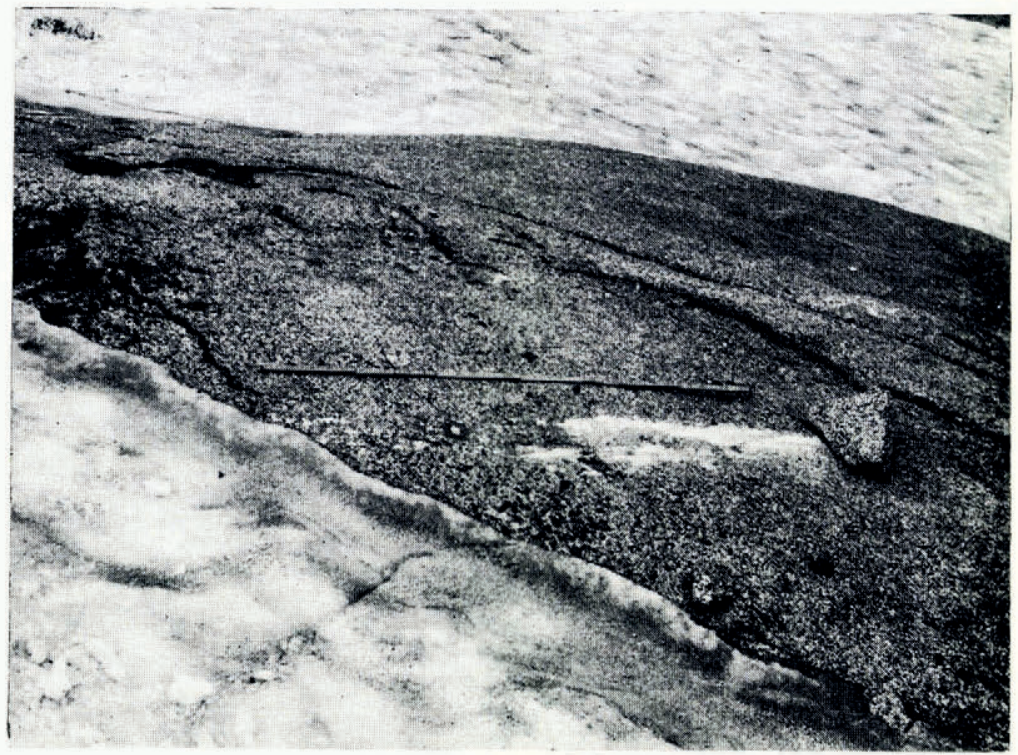

Fig. 4. Movement of stone across rock slope. Tracks extended undor undisturbed snow. (Photograph by 7. N. Jennings)

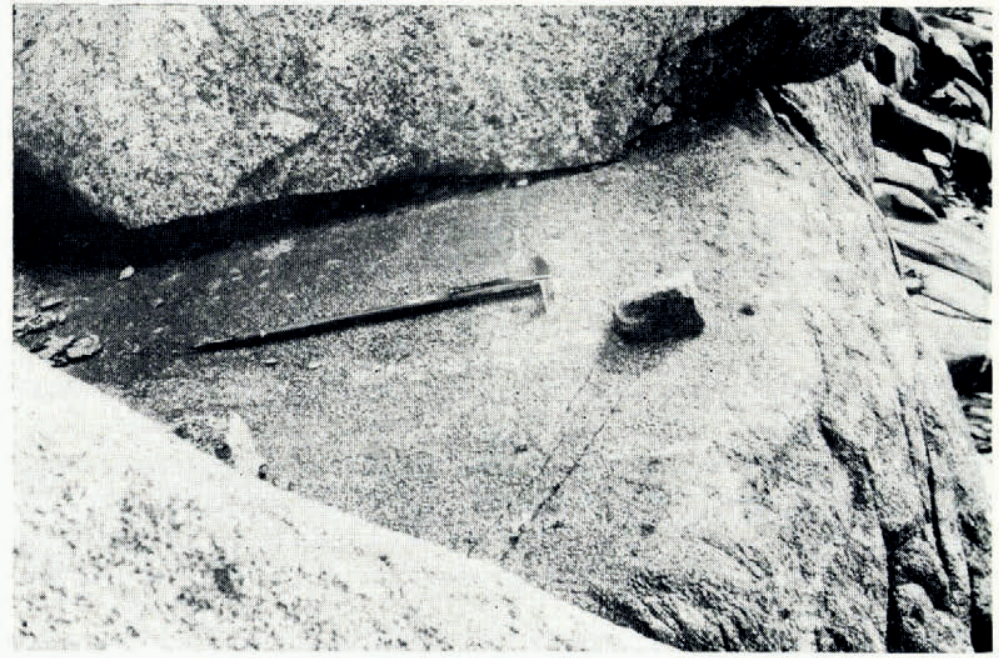

Fig. 5. Movement of stone up-slope. (Photograph by $\mathcal{F}$. N. Jennings) 
in their movement. The largest block of all could be matched with its joint-defined original home in the bedrock; it had rotated go degrees during its forward movement. A group of five others could be fitted together once more in their common starting point in the bedrock, rotation varying from 40 to 60 degrees, with one of them overturned. The fracture faces of all this group were iron-stained and it was clear that detachment from the mother rock had preceded bodily movement by some time. In a further instance, a stone had been split in two during its movement as witnessed by the fresh fracture surface. Generally speaking, however, the movements of the stones yielded only rock dust (Fig. 6) but in four cases at least tiny chips had been fractured from them. Fine scratch marks were found in both bedrock and the soles of the stones.

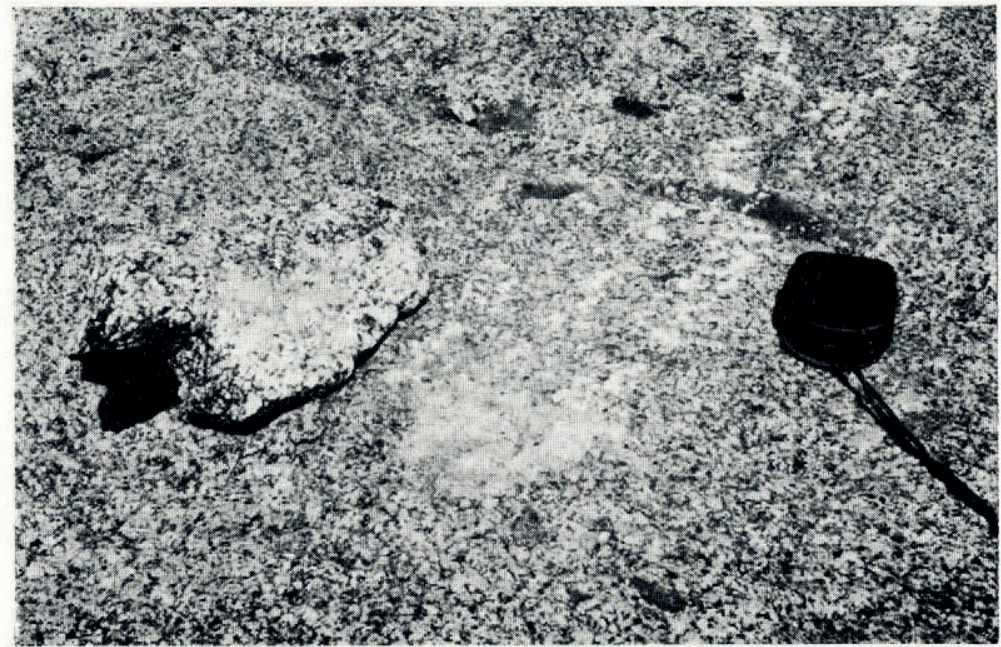

Fig. 6. Stone deliberately overturned to show abraded under-surface and rock flour. (Photograph by 7 . N. Jennings)

In addition to the abrasion marks which were white from the coating of rock flour and so interpreted as the product of movement since the previous summer, there were to be found as well occasional yellow-stained, older abrasion tracks belonging to previous years. The greatest total length of a single track measured was $23.7 \mathrm{~m}$. of which $6 \cdot 3 \mathrm{~m}$. only was fresh; the probable point of origin lay a further $4 \mathrm{~m}$. away. Three rocks had made this journey, of which the largest was $77 \times 65 \times 23 \mathrm{~cm}$. The white tracks of several stones could be traced back under the margin of the remnant snow-patch of this date.

Later, in April, further melting of the snow uncovered the areas of the paint marks of the previous year. The painted stones had all been moved down-slope from the reference paint marks on the bedrock, with the production of abrasion tracks and fresh white rock flour. In the reference area a few yards south of the snow-patch remnant, the painted stone had been moved $107 \mathrm{~cm}$. In the other reference area a few yards to the south-east of the snow-patch, one of the painted stones had been moved 2 I $8 \mathrm{~cm}$. and the other $249 \mathrm{~cm}$. The similarity of the fresh rock flour associated with the reference stones to that associated with the numerous unmarked stones measured on $16-17$ February 1963 confirmed the interpretation that the white abrasion marks were produced the previous season and the yellow-stained marks during earlier years.

At the close of the season (27-28 April 1963) with little of the cirque wall still covered, it was estimated that of the order of a thousand fresh abrasion tracks were seen. Incidentally to 
other operations, ten further stone movements were measured. The stones ranged in size from $9.2 \times 8 \cdot \mathrm{I} \times 3.7 \mathrm{~cm}$. to $88 \times 5^{8} \times \mathrm{I} 7 \mathrm{~cm}$.; the track lengths varied between 20 and $860 \mathrm{~cm}$., with a median of $8 \mathrm{o} \mathrm{cm}$. Some of the tracks observed as quite fresh earlier this summer were already becoming slightly iron-stained.

Free gravity fall of these rocks is definitely eliminated by the low-angle movement in many cases with no steep rise behind, by the steady grinding of one sole over bedrock for as much as several metres, by prolonged movements across slopes and by steady, as opposed to bouncing, uphill movements. Movement of the stones by melt water is unacceptable because of the widespread distribution of the movements, the presence of the white rock flour beneath the stones, and the movements across and up slopes.

Snow is the remaining agent possible, though the question remains whether it operated by rapid avalanche movement or by slow mass creep. The only avalanches which have been seen by the writers in this area are wind-slab avalanches or falls from cornices, which only affect the surface of the snow. Furthermore avalanches which affected the base of the snow would surely result in a far higher proportion of overturning of stones and far less steady grinding of stone against bedrock in one position. Nor is it likely that avalanches would leave stones in positions of instability. Where fresh tracks of February 1963 were traced under the margin of the snow-patch, it was obvious that the snow was undisturbed and certainly not avalanche debris. Two of the movements recorded by paintmarks lay within $5 \mathrm{~m}$. of the final snow-patch remnant, which retained its sedimentary bedding and had certainly not been subject to avalanche. Many of the marks, especially those on a big slab above the col between Little Twynam and Mount Twynam almost out of the cirque proper, were on a general slope rising gently and unlikely to produce avalanches. Moreover the many movements revealed by snow recession between February and April 1963, had taken place beneath snow which showed no sign at all of avalanche disturbance and could only have suffered mass creep. The movements and the abrasion were therefore attributed to slow mass sliding of the snow cover.

In the Snowy Mountains, slow mass sliding of the snow cover is apparently not unique to the Mount Twynam area. Several similar cases of abrasion of talus by stones, with the production of rock flour, were observed on the upper slopes of Mawson Cirque, approximately $3 \mathrm{~km}$. south of Mount Twynam, during the summers of 1962 and 1963 (Fig. 7). Examination

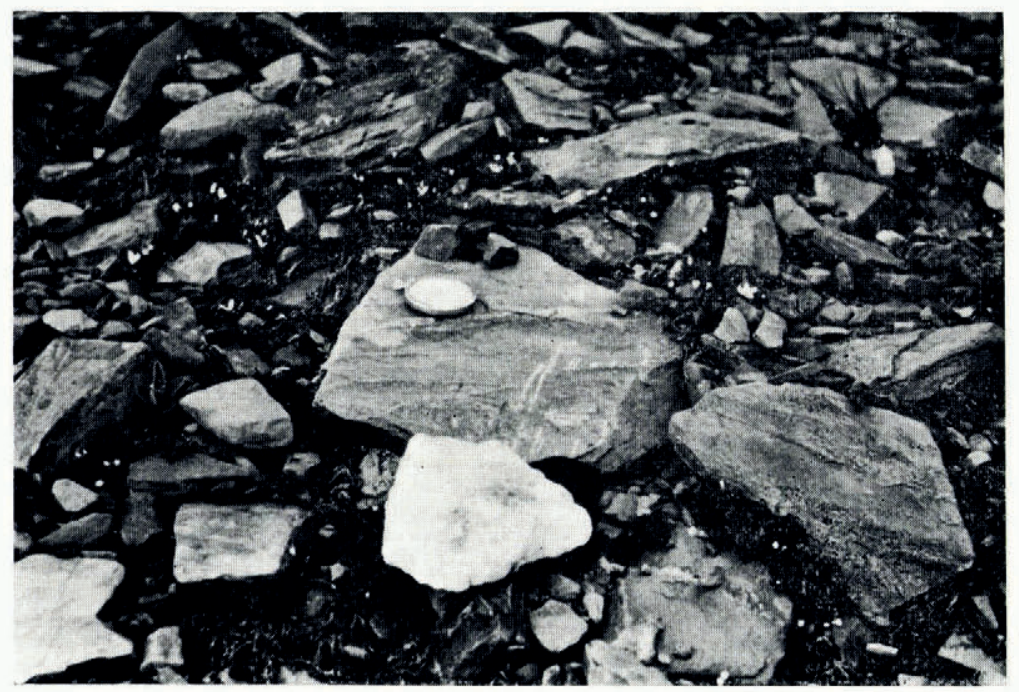

Fig. 7. Scratches on phyllite in Mawson Cirque due to movement of quartz rock. (Photograph by C.S.I.R.O.) 
of other snow-patch sites, both in the Snowy Mountains and in the Victorian Alps, would most probably reveal similar effects. Other evidence that slow mass sliding may be rather widespread, even down to elevations as low as $1,500 \mathrm{~m}$., is the twisting and bending over at ground level of steel fence posts (approximately $4 \mathrm{~cm}$. faces), under conditions where the mere weight of snow on the wires of the fence can be discounted as the bending agent. In the Mawson Cirque, angle-iron posts with approximately $15 \mathrm{~cm}$. faces have been bent over to ground level.

\section{Discussion}

Although preliminary, the data so far gathered are regarded as establishing the existence in the eastern cirque of Mount Twynam of mass sliding of snow with the concomitant transport of many stones up to quite large dimensions and the mechanical erosion both of bedrock and the moving stones themselves. The standpoint of A. N. Lewis, Rempp and Rothé, Haefeli and Maruszczak is supported in principle. However the significance of these processes needs discussion.

One point is certain; these processes render the already difficult problem of accurate determination of glacial limits in the Snowy Mountains even more difficult. The touch of glaciers in the Kosciusko area has been light and it is not always easy to distinguish between their effects and those of periglacial and nivation processes (Ritchie and Jennings [1956]). If snow-patches are capable of producing striations and even shallow grooving of resistant rocks, the task becomes harder still. Similarly, in the Victorian Alps, a polished and scratched rock surface immediately above a small cirque on Mount Howitt ( $1,742 \mathrm{~m}$.) and a striated rock from Mount Buller ( $1,802 \mathrm{~m}$.) have been interpreted, with other features, as evidence for weak glaciation (Costin, I957). Although this interpretation may still be correct, the polished and scratched surfaces referred to are now open to the alternative interpretation of slow mass sliding of snow-patch snow, and cannot, in themselves, be regarded as diagnostic features.

The question arises, however, as to whether the conditions here are especially favourable to this kind of snow action. In comparing nivation hollows and glacial cirques, previous workers have stressed the aspect of nivational preparation for glacier erosion. There is little doubt in the instance discussed here that we have the reverse relationship. Ice has fashioned a deep hollow on the leeward side of and close to the broad, flat summit of Mount Twynam where snow can now accumulate thickly and has left large areas of bare and smooth rock surface, over which stones can be moved more easily than over a soil surface. Secondly the climatic conditions of the Snowy Mountains, with their recurrent high temperatures and occasional rain during winter, may be especially favourable to firnification. Certainly very high densities of 0.5 to $0.75 \mathrm{~g} . / \mathrm{cm} .{ }^{3}$ have been determined here in snow of less than one year's age. Conditions then are conducive to mass movement and so to erosion.

Nevertheless there are certain difficulties in the way of ascribing very great erosional powers to the snow-patch. One is the presence of small vegetated peat masses amongst some of these rock surfaces which show abrasion tracks. These show little or no sign of being ripped by stones carried along by the ice. An explanation may lie in a tendency for the formation of a layer of ice over the wet peat surface in autumn, and its persistence as a protective coating under the snow until the following summer. Secondly, there is an apparent discrepancy between the large numbers of stones set in motion by the 1962 snows and the comparatively meagre accumulations of loose blocks at the foot of the cirque slope. Peat growth may help to solve this discrepancy. Though it forms slowly, it has incorporated angular blocks of granodiorite. The melt-water streams will, of course, remove some of the fragmental material brought down by the snow. In these ways material coming down the rocky slope occupied by the snow-patch is obscured or removed. By contrast Imamura (1937) has described substantial "moraines", which he regards as nivational, in the Japanese Alps. 
With regard to this problem of assessment of the significance of this form of nivational erosion, it is also possible that the $1962-63$ year was particularly favourable for the action under discussion and that other years would show far fewer abraded stones and tracks. This can only be checked by longer-term observation. A larger number of stones has been painted this autumn and also a number of open joints to measure the effects of freeze-thaw action, which prepares the ground for snow plucking and transport. Sets of steel pegs of the same height and cross-section but differing in strength have been mounted on rock slabs to permit a direct measurement of the force exerted by the moving snow. In future, attempts will be made to measure directly the mass movement of the snow; this autumn a single marker has been emplaced within the snow-patch remnant and its position surveyed in the expectation that the remnant would last through the summer and partake in any movement of the fresh snow body of the winter of 1963 . In these ways it is hoped to be able to assess more accurately how important geomorphologically are transport and erosion by the slow mass sliding of snow.

\section{AGKnowledgements}

Messrs. D. J. Wimbush and R. N. Cromer, Division of Plant Industry, C.S.I.R.O., Canberra, and Messrs. T. N. Caine and I. Douglas, School of Pacific Studies, Australian National University, Canberra, provided valuable assistance in obtaining the field measurements; this is gratefully acknowledged.

$M S$. received 5 November 1963

\section{REFERENCES}

Boch, S. G. 1946. Snezhniki i snezhnaya eroziya v severnykh chastyakh Urala [Snow patches and snow erosion in the northern part of the Urals]. Izvestiya Vsesoyuznogo Geograficheskogo Obshchestva [News of the All-Union Geographical Society], Tom 78, No. 2, p. 207-22.

Boch, S. G. 1948. Yeshche neskol'ko zamechaniy o prirode snegovoy erozii [Some further remarks on the nature of snow erosion]. Izvestiya Vsesoyuznogo Geograficheskogo Obshchestva [News of the All-Union Geographical Society], Tom 8o, No. 6, p. 6o9-II.

Bowman, I. 1916. The Andes of southern Peru. American Geographical Society, Special Publication No. 2.

Boyé, M. 1952. Névés et érosion glaciaire. Revue de Géomorphologie Dynamique, $3^{\mathrm{e}}$ An., No. I, p. 20-36.

Browne, W. R., and Vallance, T. G. 1957. Notes on some evidences of glaciation in the Kosciusko region. Proceedings of the Linnean Society of New South Wales, Vol. 82, Pt. I, p. 125-44.

Costin, A. B. 1957. Further evidence of Pleistocene glaciation in the Victorian Alps. Proceedings of the Linnean Society of New South Wales, Vol. 82, Pt. 2, p. 233-38.

Dyson, J. L. 1937. Snowslide striations. Fournal of Geology, Vol. 45, No. 5, p. 549-57.

Dyson, J. L. 1938. Snowslide erosion. Science, Vol. 87, No. 226o, p. 365-66.

Fryxell, F. M. ed. ig62. François Matthes and the mark of time. San Francisco, Sierra Club.

Galloway, R. W. 1963. Glaciation in the Snowy Mountains: a re-appraisal. Proceedings of the Linnean Society of New South Wales, Vol. 88, Pt. 2, p. 180-98.

Haefeli, R. 1953. Creep problems in soils, snow and ice. Proceedings of the third International Conference on Soil Mechanics and Foundation Engineering, Zürich, 1953, Vol. 3, p. 238-51.

Imamura, G. 1937. Past glaciers and the present topography of the Japanese Alps. Science Reports of the Tokyo Bunrika Daigaku, Sect. C, Vol. 2, p. I-6I.

Imamura, G. 1938. Quaternary glaciation of the Japanese Alps. Congrès Internationale de Géographie, Amsterdam, I938, Tom. 2, Sect. 2 A, p. $290-92$.

Imamura, G., and Hirabayasi, T. 1935. Geomorphology of the Japanese high mountains (fourth report). Nivation phenomena around the peak of Sirouma. Proceedings of the Imperial Academy of Japan, Vol. 1 I, Pt. 8, p. 33 I-33.

Lewis, A. N. 1925. Notes on a geological reconnaissance of the Mount La Perouse Range. Papers and Proceedings of the Roval Society of Tasmania for the year 1924 , p. 10-44.

Lewis, W. V. 1936. Nivation, river grading, and shoreline development in south-east Iceland. Geographical Journal, Vol. 88, No. 5, p. $43^{1}-47$.

Lewis, W. V. I939. Snow-patch erosion in Iceland. Geographical Journal, Vol. 94, No. 2, p. 153-6I.

McCabe, L. H. 1939. Nivation and corrie erosion in West Spitsbergen. Geographical fournal, Vol. 94, No. 6, p. $447-65$.

Maruszczak, H. ı96ı. Phénomènes périglaciaires dans le Pirin et sur la Vitocha (Bulgarie). Biuletyn Peryglacjalny, No. 10, p. 225-34. 
Mathews, W. H., and Mackay, J. R. 1963. Snowcreep studies, Mount Seymour, B.C.; preliminary field investigations. Geographical Bulletin, No. 20, p. 58-75.

Matthes, F. E. 19oo. Glacial sculpture of the Bighorn Mountains, Wyoming. U.S. Geological Survey. 2 ist Annual Report, [for the year] $1899-1900$, Pt. 2, p. 167-90.

Matthes, F. E. 1909. Debris tracks on the domes of the Yosemite region. Science, Vol. 30, No. 758, p. 6I-62.

Matthes, F. E. 191 I. The striped rock floor of the Little Yosemite Valley. Sierra Club Bulletin, Vol. 8, No. I, p. 3-9.

Rempp, G., and Rothé, J.-P. 1934. Sur les phénomènes actuels de nivation et d'accumulation neigeuse dans les Hautes-Vosges. Comptes Rendus Hebdomadaires des Séances de l'Académie des Sciences (Paris), Tom. 199, No. 15, p. $682-84$.

Ritchie, A. S., and Jennings, J. N. [1956.] Pleistocene glaciation and the Grey Mare Range. Fournal and Proceedings of the Royal Society of .New South Wales, Vol. 89, Pt. 2, 1955, p. 127-30.

Williams, P. J. 1962 . Quantitative investigations of soil movement in frozen ground phenomena. Biuletyn Peryglacjalny, No. I I, p. 332-60. 